\title{
Multivariate analysis of Miocene sediments: Rákóczi Square, new metro station area, Budapest, Hungary
}

Nikolett Bodnár

Department of Construction Materials and Engineering Geology, Budapest University of Technology and Economics, Budapest

Ákos Török*

Department of Construction Materials and Engineering Geology, Budapest University of

Technology and Economics, Budapest
József Kovács

Department of Applied Geology

Eötvös Loránd University, Budapest

\begin{abstract}
Miocene siltstone with variable sand content and bentonitic clay is the most abundant sediments encountered at the metro construction site at Rákóczi Square (Budapest). Core logs, drilling reports and records of laboratory analyses were studied to better understand the local geology and to prepare a database on engineering geologic properties of the materials. Using this database, geologic sections were prepared and geomathematical methods were used to obtain a better correlation of the strata in the area and a reconstruction of the geologic evolution of the area. The samples were divided into five groups based on physical properties. These five parameters allowed the use of multivariate statistical methods as cluster and discriminant analysis. As a result it was possible to identify several types of lithotypes, including two bentonitic clays with substantially different properties, one fat clay, one medium clay and one sandy, lean clay and siltstone group.
\end{abstract}

Keywords: bentonite, clay, cluster analysis, geomathematics, metro

\section{Introduction}

The aim of the study was the engineering geologic analysis of the surroundings of Rákóczi Square (Budapest, Hungary), one of the stations of the new Budapest metro line 4 (Fig. 1). The station is under construction and therefore several corings and borehole analyses were performed prior to beginning work.

This study is necessary because it helps to better understand the area and could provide important data for the construction. The understanding of the

Addresses: N. Bodnár, Á. Török: H-1111 Budapest, Múegyetem rkp. 3, Hungary

J. Kovács: H-1117 Budapest, Pázmány P. stny. 1/c, Hungary

*Corresponding author; e-mail: torokakos@mail.bme.hu

Received: March 10, 2011; accepted February 28, 2012 
392 N. Bodnár et al.

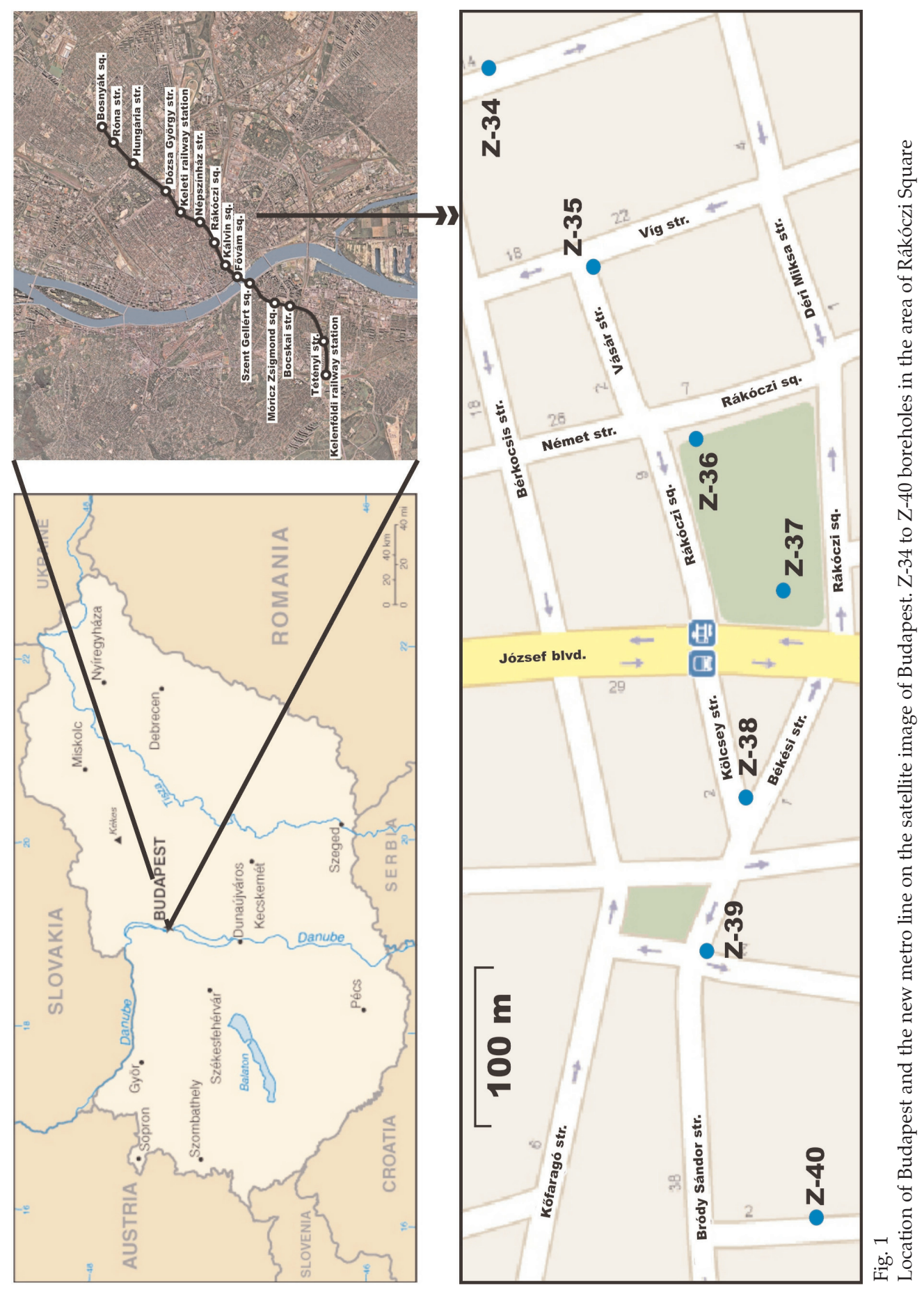

Central European Geology 54, 2011 
geology of Budapest is indispensable because of the continuous development of the underground system of the capital of Hungary.

The understanding of the region is based on previous studies, which must be used with caution. The most important data were obtained from the descriptions of the previous corings and from studying the exposure during the construction of the station at Rákóczi Square. Newly-prepared geologic sections are based on the descriptions of the boreholes and the geomathematical analysis of the laboratory test results. These new findings could help in the correlation of the strata and the reconstruction of the geologic evolution of the area. The present study focuses on the engineering geologic parameters of the core data obtained from the area of Rákóczi Square. Multivariate statistical methods were used, which have not previously been applied in this context.

\section{Geology}

Geologic settings

The topography of Budapest is divided into two parts by the river Danube. On the west side of the river are the Buda Mountains and on the east side is the Pest Plain. The morphology of the Buda Mountains is governed by faults and thrust belts (Fodor et al. 1994). The Pest Plain is continuously being filled with alluvial flat sediments (Schafarzik et al. 1964).

The greatest difference in elevation of the South Buda - Rákospalota metro line number 4 between Kelenföld railway station and Baross Square (Keleti or Eastern railway station) is only 11 meters. The highest point of the line is located at Kelenföld railway station (114-112.5 asl). The lowest part of the line is located between the Etele Square-Bártfa Street and Sárbogárd Road and the area between Fôvám Square and Rákóczi Square (103-104 asl). The present topography is flat, but that is a result of human activity. With the exception of the areas closest to the Danube, the most intensive human activity was the drying out of previous swampy areas and thick anthropogenic fill of river meanders.

In the immediate vicinity of the new metro line, Eocene sediments were unconformably deposited on Upper Triassic beds (Main Dolomite). Sedimentation began in the Late Eocene (Kecskeméti 1998; Fodor et al. 1994) (Fig. 2). Along the metro line the Eocene, Oligocene and Miocene strata are covered by Quaternary sediments.

The metro line can be divided into three parts on the basis of geologic-tectonic settings: the Buda section (from Kelenföld railway station to Gellért Square), the Danube crossing part (from the western end of Gellért Square to Pest Lower Quay) and the Pest section (from Fôvám Square to Keleti railway station, Dózsa György Street) (Raincsákné 2000).

The Buda part is relatively homogeneous in terms of its geologic setting. It is moderately tectonized (Geovil 2005). On the Buda side the tunnels were cut in the Kiscell Clay (Lower Oligocene, bathyal facies; Báldi 1983). This is overlain by 


\begin{tabular}{|c|c|c|c|}
\hline Series & Lithology & Stratigraphy & Short description \\
\hline Quaternary & & Quaternary sediments & \\
\hline $\begin{array}{l}\text { Pannonian } \\
\text { s.l. }\end{array}$ & & $\begin{array}{c}\text { Pannonian s.l. } \\
\text { sediments }\end{array}$ & \\
\hline \multirow{11}{*}{ Rákóczi sq. } & & $\begin{array}{c}\text { Galgavölgy Rhyolite } \\
\text { Tuff Formation }\end{array}$ & $\begin{array}{c}\text { biotitic vesicular rhiolite tuff } \\
\text { with dacite-, andesite-bearing } \\
\text { volcanoclastics }\end{array}$ \\
\hline & & $\begin{array}{c}\text { Budajenő } \\
\text { Formation }\end{array}$ & $\begin{array}{l}\text { laminar silt, silty clay marl with } \\
\text { dolomite, sulphur, gypsum, } \\
\text { and anhydrite stringers }\end{array}$ \\
\hline & & $\begin{array}{c}\text { Tinnye } \\
\text { Formation }\end{array}$ & $\begin{array}{c}\text { biogenic limestone, calcareous } \\
\text { sandstone and calcareous } \\
\text { molluscan sand }\end{array}$ \\
\hline & & $\begin{array}{l}\text { Rákos Limestone } \\
\text { Formation }\end{array}$ & $\begin{array}{l}\text { lithothamnium limestone and } \\
\text { molluscan limestone } \\
\text { of reef origin }\end{array}$ \\
\hline & & $\begin{array}{l}\text { Mátra Andesite } \\
\text { Formation }\end{array}$ & $\begin{array}{c}\text { dominantly amphibole andesite } \\
\text { and its pyroclastics }\end{array}$ \\
\hline & & $\begin{array}{c}\text { Perbál } \\
\text { Formation } \\
\end{array}$ & $\begin{array}{l}\text { terrestrial variegated clay, silt } \\
\text { and fine-grained sandstone } \\
\text { with tuff intercalations }\end{array}$ \\
\hline & & $\begin{array}{l}\text { Tar Dacite Tuff } \\
\text { Formation }\end{array}$ & biotitic vesicular dacite tuff \\
\hline & & $\begin{array}{c}\text { Fót } \\
\text { Formation } \\
\end{array}$ & $\begin{array}{l}\text { Bryozoa-Balanus-bearing } \\
\text { calcarenite,calcareous } \\
\text { sandstone with pebbles }\end{array}$ \\
\hline & & $\begin{array}{l}\text { Egyházasgerge } \\
\text { Formation }\end{array}$ & $\begin{array}{l}\text { frequently cross-bedded } \\
\text { Chlamys-bearing sand and } \\
\text { sandstone }\end{array}$ \\
\hline & & $\begin{array}{l}\text { Gyulakeszi Rhyolite } \\
\text { Tuff Formation }\end{array}$ & $\begin{array}{c}\text { generally homogeneous, } \\
\text { thick-bedded, ignimbritic } \\
\text { rhiolyte tuff }\end{array}$ \\
\hline & & $\begin{array}{c}\text { Zagyvapálfalva } \\
\text { Formation }\end{array}$ & $\begin{array}{c}\text { fluvial floodplain sequence } \\
\text { consisting of variegated silt, } \\
\text { gravel and sand }\end{array}$ \\
\hline \multirow{4}{*}{ Oligocene } & 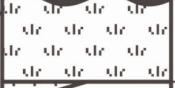 & \begin{tabular}{|c|} 
Becske \\
Formation \\
\end{tabular} & $\begin{array}{l}\text { marshy-fluvial formation with } \\
\text { marine intercalations }\end{array}$ \\
\hline & & $\begin{array}{l}\begin{array}{l}\text { Törökbálint } \\
\text { Sandstone }\end{array} \text { Szécsény } \\
\text { Formlier } \\
\text { Formation Formation }\end{array}$ & $\begin{array}{c}\text { coarse- and } \\
\text { fine-grained } \\
\text { sandstone }\end{array}$ \& $\begin{array}{l}\text { argillaceous } \\
\text { siltstone with } \\
\text { clay marl and }\end{array}$ \\
\hline & & \begin{tabular}{|c|}
$\begin{array}{c}\text { Kiscell Clay } \\
\text { Formation }\end{array}$ \\
\end{tabular} & clay, clay marl, calcareous silt \\
\hline & 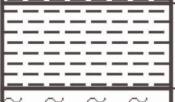 & $\begin{array}{l}\text { Tard Clay } \\
\text { Formation }\end{array}$ & micro-laminated anoxic clay \\
\hline \multirow[b]{2}{*}{ Eocene } & & $\begin{array}{l}\text { Buda Marl } \\
\text { Formation }\end{array}$ & $\begin{array}{l}\text { clay or calcareous marl } \\
\text { the lower part contains Bryozoa }\end{array}$ \\
\hline & & $\begin{array}{c}\text { Szépvölgy Limestone } \\
\text { Formation }\end{array}$ & bioclastic limestone \\
\hline $\begin{array}{l}\text { Upper } \\
\text { Triassic }\end{array}$ & $\begin{array}{|llll|} & 7 & 1 \\
& 1 & 1 & 1 \\
& 1 & 1 & 1 \\
& 1 & 1\end{array}$ & $\begin{array}{c}\text { Main Dolomite } \\
\text { Formation }\end{array}$ & $\begin{array}{l}\text { microcrystalline, thick-bedded, } \\
\text { platform carbonate }\end{array}$ \\
\hline
\end{tabular}

Fig. 2

Lithostratigraphic column of the Budapest area showing the Miocene formations of the Rákóczi Square area 
the Tard Clay. The thickness of the Kiscell Clay depends on the tectonic setting. At Kelenföld Plain it is at least 250-400 meters thick, while near Gellért Square it is eroded and is only 13-22 meters in thickness. The deposits of the Kiscell Clay Formation are typically thick-bedded of grey-bluish grey color. Pyrite is a common accessory mineral and in the cracks gypsum is found. It is dominantly clay with minor silt content and medium carbonate content (Geovil 2001, 2005).

The part of the line that crosses the Danube was cut through an asymmetric tectonic horst (showing stronger compression in the northeastern part) at the southeastern section of Gellért Hill. It is subdivided by NW-SE-trending faults. The formations older than Lower Oligocene are on the downthrown side of the fault system on the Pest side (Rózsa and Fáy 1980). These formations are at present at a depth of over 1000 meters at the Pest side.

The sediments become younger from the SW to NE on the other river bank, in Pest. The line is cut through Upper Oligocene and Miocene strata. This part is lithologically more diverse. The Oligocene and Miocene beds are covered by fluvial deposits of the Danube, which contain groundwater (Juhász 2000). From Szabadság Bridge (Pest side) the line goes into the sandy, subtidal to intertidal Upper Oligocene deposits of the Törökbálint Sandstone Formation. At a distance of 150 meters from the Danube toward Kálvin Square the geology changes and the line passes into the overlying beds of the Szécsény Schlier Formation due to several faults that resulted in the uplift of the schlier. Approximately $150 \mathrm{~m} \mathrm{SW}$ of Kálvin Square the pebbly, sandy, clayey sediments of the litoral-sublitoral Budafok Formation are found (Rózsa and Fáy 1980). From Kálvin Square to Fiume Road the line runs within Badenian sediments, which can be divided into lower tuffitic/terrigenous sediments and Upper Badenian marine ones. The tuffitic part of the Badenian is considered to be coeval with the Tar Dacite Tuff ("Middle Rhyolite Tuff") (Bubics 1978). It is usually windborne but of variable facies; unstratified and stratified aquatic sediments are found. Two hundred meters past Kálvin Square the metro line was cut through tuffitic beds, which is covered by terrestrial, variegated clay, silt and fine-grained sandstone with tuff and tuffitic intercalations and variegated siltstone of the Perbál Formation from Rákóczi Square to Fiume Street. Between Rákóczi and the Köztársaság Squares three major normal faults were encountered (Geovil 2005). From Fiume Road to Baross Square (Keleti railway station) the line was cut through Badenian and Sarmatian marine sediments represented by the Rákos Limestone and Tinnye Limestone Formations.

The groundwater flow is primary controlled by the Danube. There are two main flow directions. One is toward the erosion base (Danube), while the second one follows the Danube valley and is predominantly set in a NW-SE direction. Flow channels and elevated groundwater tables are found, which means that the groundwater system is not uniform. The water level of the Danube influences the water-level of the nearby terraces and groundwater tables (Juhász 2000). Deep, lukewarm karstic water is typical for the Gellért Square area, where Triassic dolomite supplies ascending thermal waters (Geovil 2005). 


\section{Cross-sections}

The studied cores are from Rákóczi Square and the surrounding area (center of Budapest) (Fig. 3). The corings were made for the site survey of the new metro line and to provide data for the engineering geologic design of the Rákóczi Square metro station. There were two drilling campaigns: the first set of cores was cut in 1972 (these are marked with Z), while the second series of cores were obtained in 2006. On the cross-sections, for simplicity the pebble and sand beds are illustrated as sand; the mud, the silt, lean clay, medium clay and fat clay are shown as clay, and the bentonite and bentonitic clays are illustrated as bentonite. Clayey sediments prevail in the study area, while sandy and bentonitic intercalations are less common (Fig. 4). The river deposits of the Danube, with pebbly sand and sand, and the anthropogenic filling with the soil cover, represent the upper 10-12 meters of the sections. The thickness and the frequency of the bentonitic intercalations become more common below a relative depth of 30 meters below the surface.

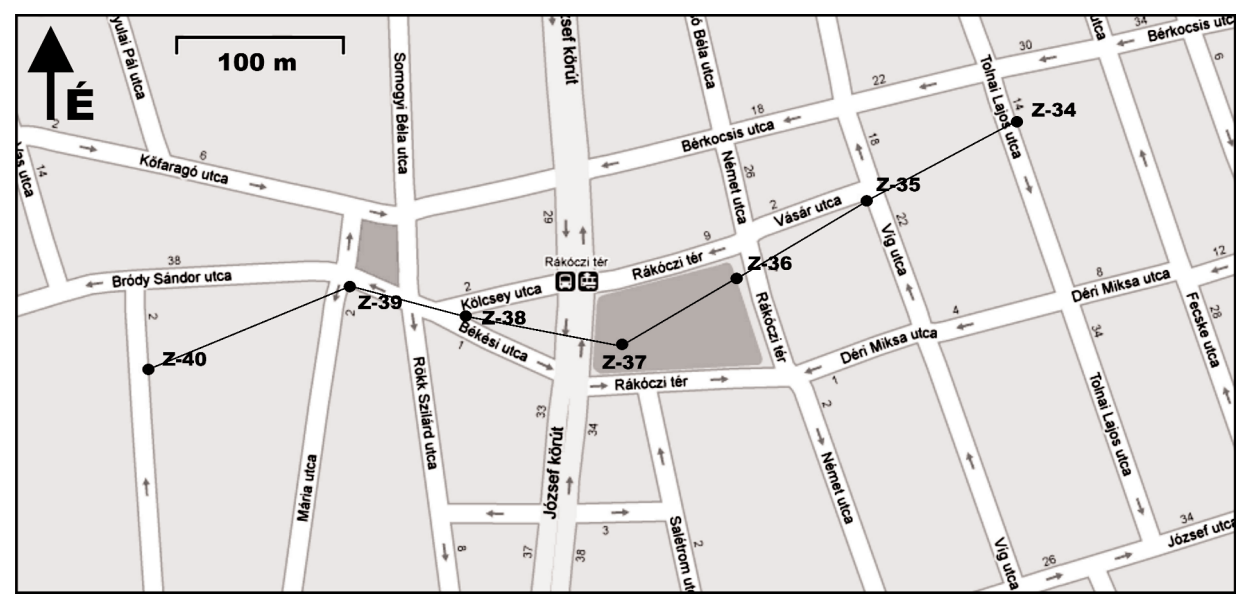

Fig. 3

The site with the boreholes and cross-section line

Fig. $4 \rightarrow$

Two adjoining cross-sections from the Rákóczi Square area

Central European Geology 54, 2011 


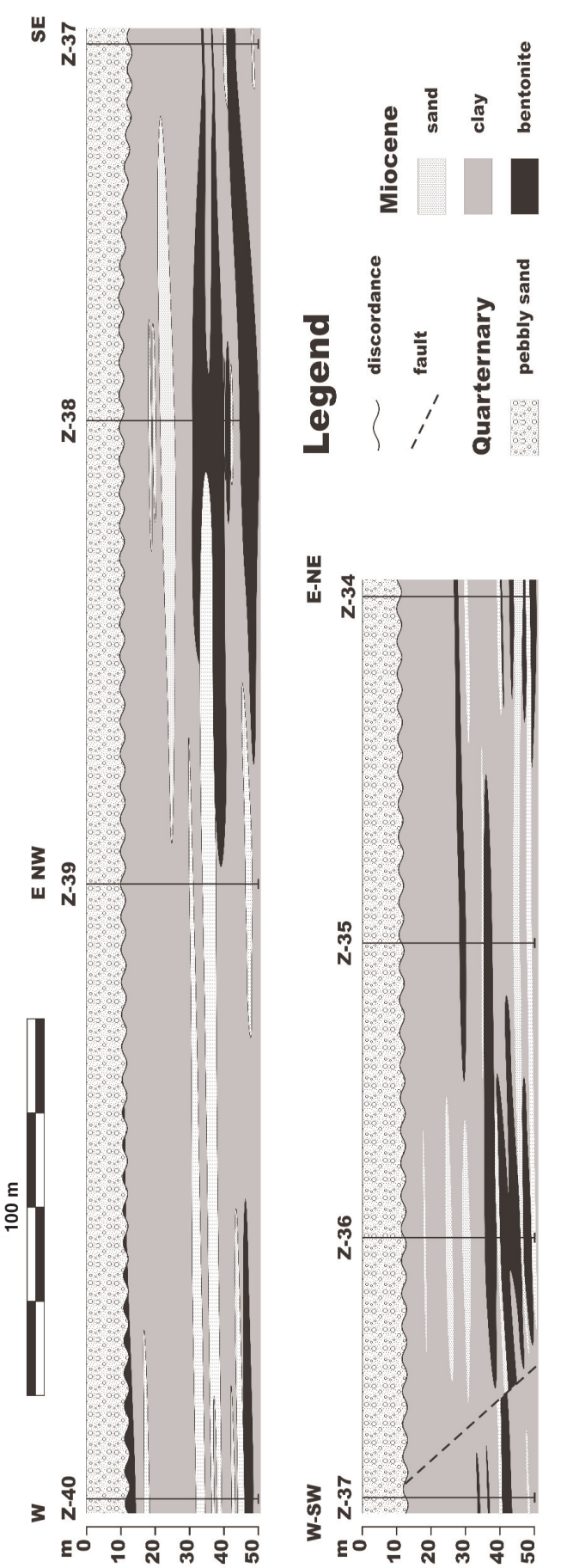

\section{Engineering geologic parameters}

The data used in this study was obtained from borehole logs and core descriptions. Additionally results of previous laboratory analyses and engineering geologic reports were used. A dataset from seven coreholes was used for the statistical analyses. From the measured and reported engineering geologic properties of cores, twelve parameters were selected for the analyses. These include the index of plasticity, skewness, the void ratio, water content, dry and water-saturated bulk density, angle of friction, cohesion, compressive strength, water conductivity, and $\mathrm{CaCO}_{3}$ content. The data source was not uniform since at several depths, not all the parameters were measured; the missing data thus make it more difficult to evaluate the engineering geologic parameters. As a consequence, only those core intervals were used where most of these values were available.

The dataset was grouped into five units according to lithology. The engineering geologic parameters of the mud, the non-swelling clay, the medium clay, the swelling clay and the bentonite layers were processed, while gravel and the sand beds were not considered since several of these parameters (e.g. index of plasticity) cannot be defined for such lithologies. Data filtration of the selected and gathered twelve parameters showed that there are very poor correlations between several 
properties; thus these values should not be taken into consideration in multivariate statistical methods. After filtration only five parameters remained including void ratio, dry bulk density, angle of friction, cohesion and compressive strength. Fifty-four samples containing 270 data were analyzed by the means of mathematical statistics.

\section{Mathematical-statistical methods}

Cluster analysis is a multivariate statistical method, which is used to form groups from different samples according to their similarity. These groups are the clusters. The bases of the grouping are the different similarity or distance values. It should be pointed out that there is no need for any advance knowledge regarding the groups. This is the reason why the results must be tested with discriminant analysis. Using this method it can be verified how much the planes separating the groups can be distinguished. The result of discriminant analysis is often visualized on the surface stretched between the first two discriminating planes (function 1 and function 2). It was also discovered which parameters played the greatest role in determining the formations of the cluster groups during cluster analysis. This method is also known as the Wilks' lambda distribution method.

The acquired cluster groups' statistics can be presented together on box-andwhiskers plots. The abscissa shows the clusters and on the ordinate the parameters can be seen. Fifty percent of the data (interquartile range) lie in the "boxes". The lower border of the "boxes" represents the lower quartile and the upper boundary the upper quartile. The black (level) line in the "box" represents the median. The two upright lines in the boxes represent 1.5 times the interquartile range; the circles represent the outlier and the asterisks the extreme values (IBM 2010).

\section{Results of statistical analyses}

The cluster analysis of 54 samples of the five parameters resulted in five groups (Fig. 5). The samples were not evenly assigned into the five groups. In some groups more samples were found and in some other clusters fewer ones. In the first group 8 , in the second 3, in the third 28 , in the fourth 11 , while in the fifth group 4 samples were identified.

Wilks' lambda distribution calculations have shown that dry bulk density (Wilks' Lambda: 0.18) had the greatest influence on the grouping, while the angle of friction (Wilks' Lambda: 0.58) had the least. Between these two end points are the void ratio (Wilks' Lambda: 0.23), the cohesion (Wilks' Lambda: 0.22) and compressive strength (Wilks' Lambda: 0.27).

The groups created with the cluster analysis were verified with discriminant analysis, which proved that the groups were mathematically correct. 
Grouping of the 54 samples on the basis of the void ratio, dry bulk density, friction angle, cohesion and compressive strength

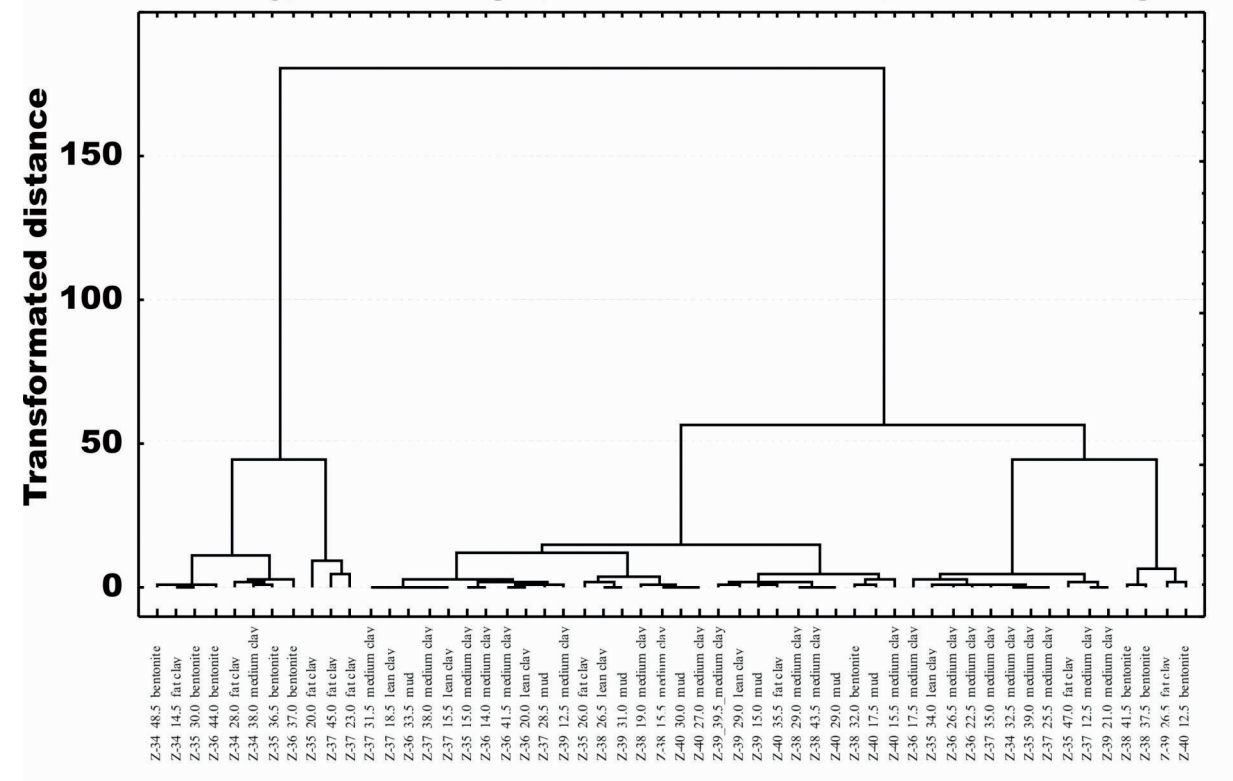

Fig. 5

Results of cluster analyses

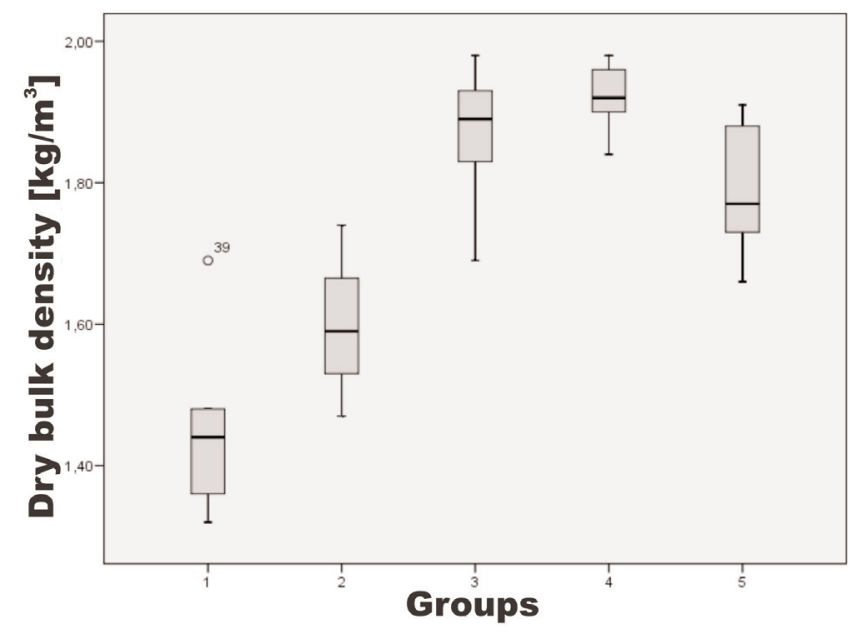

Fig. 6

Geostatistical grouping of samples based on the dry bulk density 
The statistics of the dry bulk density (Fig. 6) showed that the first and second groups had the lowest values of all the groups. The most uniform group was the fourth one and the least evenly distributed was the third. The first cluster had one outlier.

The distribution of the void ratio (Fig. 7) indicated that the first and second cluster had higher values than the third, fourth and the fifth ones. The first group had a wider interquartile range than the others. The fourth cluster had one outlier. The median of the second group was close to the lower quartile, while for the fourth group the median and the upper quartile were almost the same. For those clusters where the values of the void ratio were high the values of the dry bulk density were low. The groups with low void ratios showed high values of dry bulk density. This indicated that these parameters showed reverse proportionality in the groups.

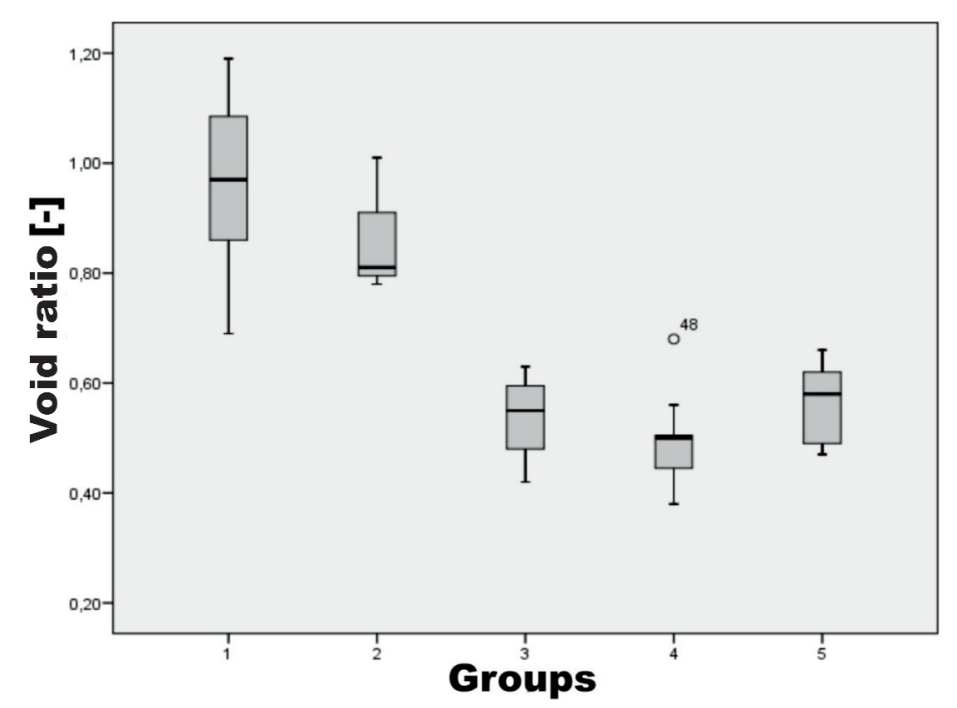

Fig. 7

Geostatistical grouping of samples based on void ratio

On the basis of the cohesion values the clusters were more compact than for the other parameters (Fig. 8). The second group had the highest values while the values of the other groups were almost the same. The fourth cluster had one outlier. The medians of the second and the fourth clusters were close to the lower quartile.

Based on the distribution of compressive strength the groups had different values and interquartile range as well (Fig. 9). The values of the fifth cluster were much higher than the ones of the other groups and in this cluster the median was 
Multivariate analysis of Miocene sediments: Rákóczi square, new metro station area, Budapest 401

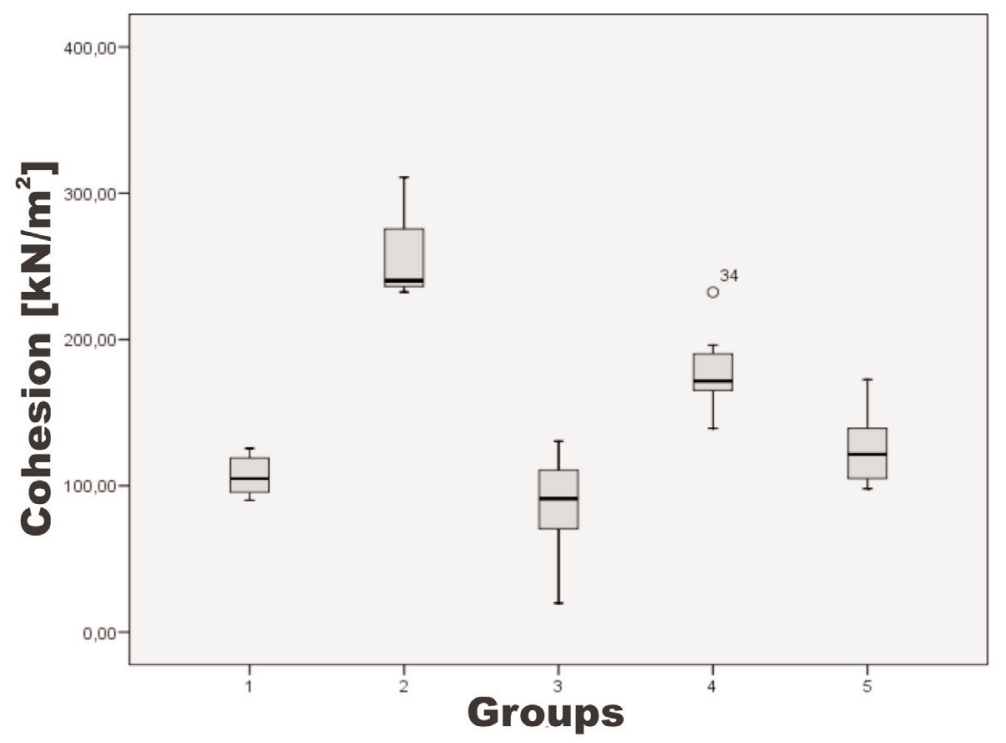

Fig. 8

Geostatistical grouping of samples based on cohesion

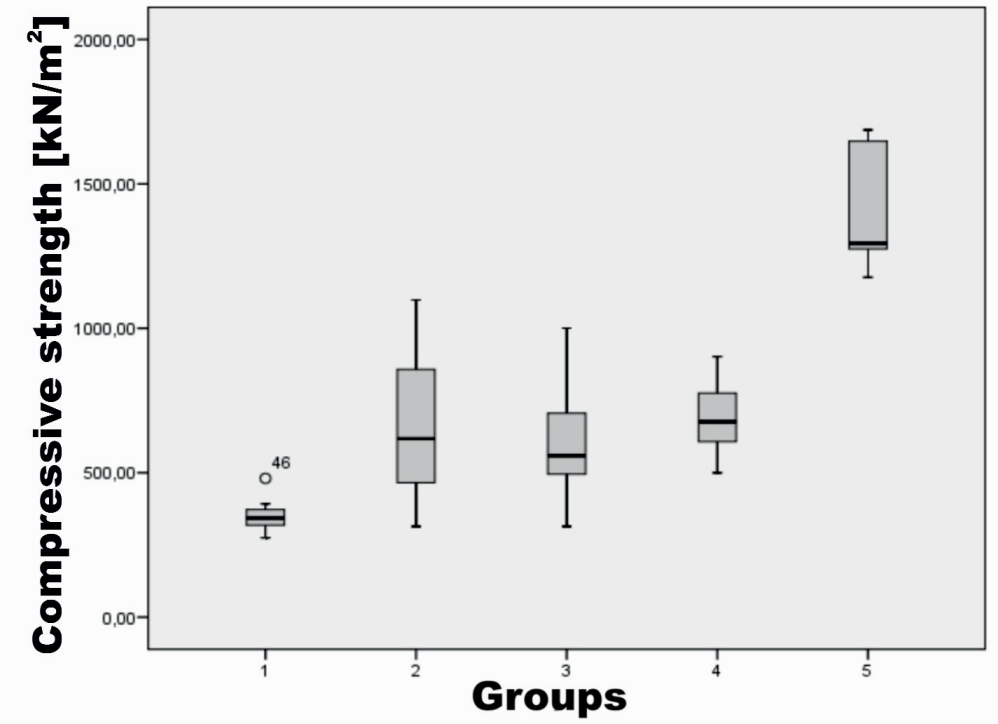

Fig. 9

Geostatistical grouping of samples based on compressive strength 
close to the lower quartile. The first group had a smaller interquartile range than the others and it had one outlier.

On the basis of the friction angle grouping the distributions of the groups were very variable (Fig. 10). The first and the fifth groups had minor interquartile ranges while the fourth had a major one. The third cluster had one outlier and the fifth had one extremely low data point.

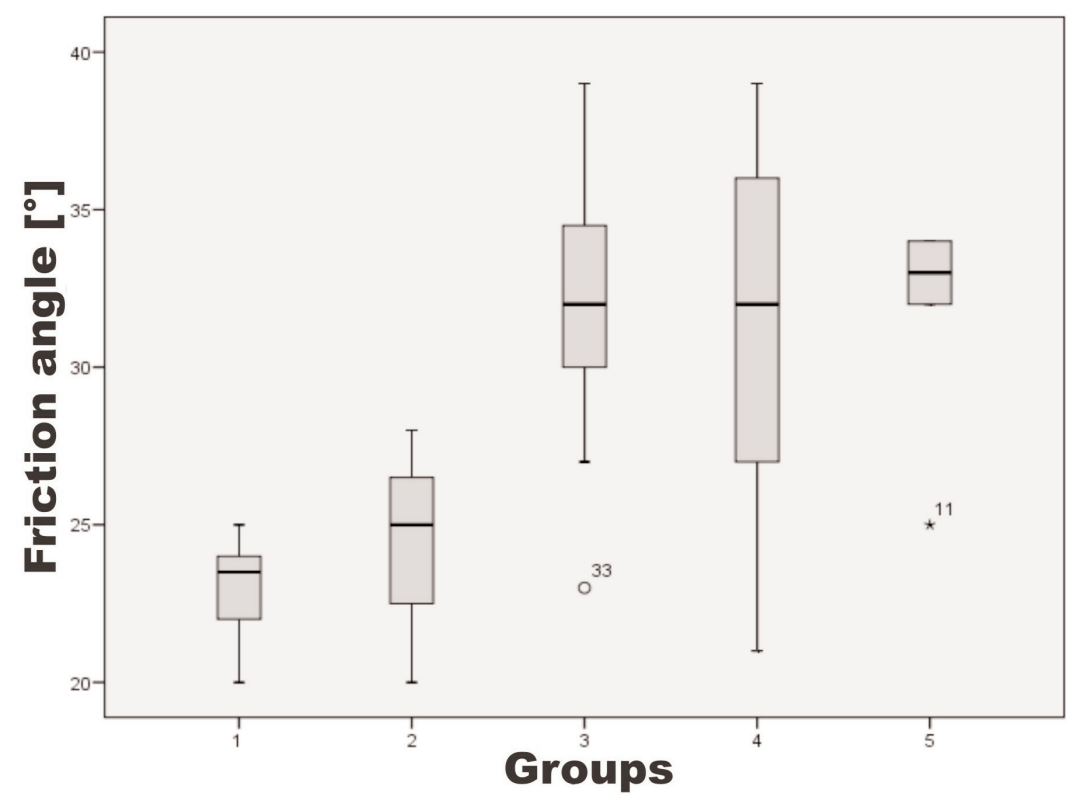

Fig. 10

Geostatistical grouping of samples based on friction angle

\section{Interpretation}

Each group can be classified by using the engineering geologic parameters listed above. The samples, which are in the same cluster, are of similar composition, indicating that they were deposited in a very similar environment. Unfortunately, rock samples were not available and thus the interpretation is an assumption. Table 1 summarizes the major lithologies of the five main groups and the ranges of the values of the each group.

In the first and the fifth group most of the samples belong to bentonite. The samples of the first group are from the Z-34, the Z-35 and the Z-36 cores, while the samples of the fifth are from the Z-38, the Z-39 and the Z-40 ones. The samples of these two groups can be separated. This could be interpreted as two engineering geologically-distinct bentonites that were formed as a result of the decomposition of the products of two distinct volcanic events. Alternatively, 
Table 1

Major lithologies of the five main groups and the ranges of the engineering geologic properties

\begin{tabular}{|l|c|c|c|c|c|c|}
\hline $\begin{array}{l}\text { Id. } \\
\text { number } \\
\text { of groups }\end{array}$ & $\begin{array}{c}\text { Lithology } \\
\text { of groups }\end{array}$ & $\begin{array}{c}\text { Dry bulk } \\
\text { density }\left[\mathrm{kg} / \mathrm{m}^{3}\right]\end{array}$ & $\begin{array}{c}\text { Void ratio } \\
{[-]}\end{array}$ & $\begin{array}{c}\text { Cohesion } \\
{\left[\mathrm{kN} / \mathrm{m}^{2}\right]}\end{array}$ & $\begin{array}{c}\text { Compressive } \\
\text { strength } \\
{\left[\mathrm{kN} / \mathrm{m}^{2}\right]}\end{array}$ & $\begin{array}{c}\text { Friction } \\
\text { angle }\left[{ }^{\circ}\right]\end{array}$ \\
\hline 1 & bentonite & $1.32-1.69$ & $0.69-1.19$ & $90-125$ & $275-480$ & $20-25$ \\
\hline 2 & swelling clay & $1.47-1.74$ & $0.78-1.01$ & $232-310$ & $314-1098$ & $20-28$ \\
\hline 3 & $\begin{array}{c}\text { sandy non- } \\
\text { swelling clay } \\
\text { and mud }\end{array}$ & $1.69-1.97$ & $0.42-0.63$ & $20-130$ & $314-1176$ & $27-39$ \\
\hline 4 & medium clay & $1.84-1.98$ & $0.38-0.68$ & $139-232$ & $500-902$ & $21-39$ \\
\hline 5 & bentonite & $1.66-1.98$ & $0.47-0.66$ & $90-173$ & $1000-1686$ & $25-34$ \\
\hline
\end{tabular}

following deposition, different diagenetic processes came into play and caused the differences in these parameters. There is a fault between the Z-36 and the Z38 locations, which is not synsedimentary; thus this fault did not affect the depositional processes and syndiagenesis.

There are only three samples in the second cluster, which according to lithological descriptions belong to yellow expandable clays. The yellow color indicates that the samples of the group might be of similar mineralogical composition, which is different from other clays described in the core logs; this is probably the reason why these samples are distinct from the others.

All the samples of the fourth group are medium clays. These samples were found in many analyzed locations without any specific lithological description. Consequently the samples in this cluster are considered to typical medium clays.

The third group is complex because half of the analyzed samples belong to this cluster. In this group all of the mud and the lean clays (with one exception) are found. On the basis of the lithological descriptions it can be seen that the samples of this group are almost always moderately sandy. Based on these findings the third cluster incorporates the sandy clay and the clay with higher mud content.

\section{Conclusions}

The geologic description and core data show that the prevailing lithotype in the area of the Rákóczi Square metro station consists of clay with variable sand and mud content and with bentonite intercalations.

A fault was identified in the area based on the newly prepared cross-sections.

Twelve engineering geological parameters were gathered from the laboratory analyses of 13 previously cored locations for geomathematical analyses, but after filtering only five properties were appropriate for geomathematical analyses. These parameters were void ratio, dry bulk density, angle of friction, cohesion and compressive strength.

Cluster and discriminant analysis of 54 samples and 270 engineering geologic data allowed the distinction of five groups. These included two groups of 
bentonites with substantially different properties, one group of swelling clay, one of medium clay and one of sandy and muddy clay.

This study has proved that the use of geomathematical and multivariate statistical methods allows the evaluation of poorly-described and very mixed laboratory and lithological datasets, and provides valuable information for geologic interpretation. It is especially important when no additional sampling is possible and only a mixture of old borehole data and new laboratory analyses are available.

Under very complex engineering geologic settings, when different lithologies with different physical parameters are found, geomathematical analyses are also useful tools in the representation of datasets and in the selection of proper physical parameters for the design of an engineering structure.

\section{Acknowledgements}

This work is connected to the scientific program of the "Development of quality-oriented and harmonized $\mathrm{R}+\mathrm{D}+\mathrm{I}$ strategy and functional model at BME" project. This project is supported by the New Széchenyi Plan (Project ID: TÁMOP-4.2.1/B-09/1/KMR-2010-0002).

The help of Tibor Horváth, Béla Kleb and Péter Görög in the interpretation of results are appreciated. János Buri, Zoltán Buri and Ferenc Horváth provided access to the construction site at Rákóczi Square. Ildikó Barsi and Attila Virág helped in the preparation of the graphics.

\section{References}

Báldi, T. 1983: Magyarországi oligocén és alsómiocén formációk (Hungarian Oligocene and Lower Miocene Formations). - Akadémiai Kiadó, Budapest, 293 p. (In Hungarian.)

Bubics, I. 1978: A budapesti metróépítés földtani eredményei. (Geological findings during the construction of Budapest metro line) - Mérnökgeológiai Szemle, 21, pp. 5-87. (In Hungarian.)

Fodor, L., Á. Magyari, A. Fogarasi, K. Palotás 1994: Tercier szerkezetfejlődés és késő paleogén üledékképződés a Budai-hegységben. A Budai-vonal új értelmezése (Tertiary tectonic evolution and Late Paleogene sedimentation in Buda Mountains. The new interpretation of Buda line). Földtani Közlöny, 124/2, pp. 129-305. (In Hungarian.)

Geovil Kft. 2001: A metróvonal és környezetének földtani felépítése (B. fejezet) (Geology of metro line and its environment (chapter B)). - manuscript, Szentendre, Geovil Kft., 34. p. (In Hungarian.)

Geovil Kft. 2005: Budapest 4. metróvonal, I. szakasz, Összefoglaló mérnökgeológiai, hidrogeológiai és geotechnikai szakvélemény, "A" kötet, Természetföldrajzi és földtani adottságok a nyomvonal mentén. Szentendre (Budapest metro line no. 4, section I. Summary report on engineering geology, hydrogeology and geotechnics. Volume "A", Geography and Geology along the line). - Geovil Kft., 25. p (In Hungarian.)

IBM 2010: Introduction to statistical analysis with PASW Statistics. - IBM Company, Chicago IL, USA, 274. p.

Juhász, J. 2000: A 4. sz. metró kutatásának hidrogeológiai eredményei (Hydrogeological results of the metro line 4). - Földtani Kutatás, 37/2, pp. 25-35. (In Hungarian.) 
Kecskeméti, T. 1998: Magyarország epikontinentális eocén képződményeinek rétegtana (fStratigraphy of epicontinental Eocene of Hungary). - In: Bérczi, I., Á. Jámbor (Eds): Magyarország geológiai képződményeinek rétegtana. A MOL Rt. és a MÁFI kiadványa, Budapest, pp. 403-417. (In Hungarian.)

Raincsákné, Gy. 2000: A Budapest 4. sz. metróvonal és környezetének földtani viszonyai (Geological conditions of Budapest metro line no 4). - Földtani Kutatás, 37/2, pp. 4-19. (In Hungarian.)

Rózsa, L., M. Fáy 1980: Újabb adatok Budapest talajviszonyairól a metró feltárások alapján (New data on the ground conditions of Budapest based on the explorations of the metro line). Mélyépítéstudományi Szemle, 30/1, pp. 1-8. (In Hungarian.)

Schafarzik, F, A. Vendl, F. Papp 1964: Geológiai kirándulások Budapest környékén (Geological excursions in the surroundings of Budapest). - Múszaki Könyvkiadó, Budapest, 296. p. (In Hungarian.) 